\title{
Dari Fomo ke Jomo : Mengatasi Rasa Takut akan Kehilangan (Fomo) dan Menumbuhkan Resiliensi terhadap Ketergantungan dari Dunia Digital
}

\author{
Seprianus Kiding', Andik Matulessy ${ }^{2}$ \\ ${ }^{1}$ Magister Psikologi Fakultas Psikologi Universitas 17 Agustus 1945 Surabaya, Indonesia \\ Fakultas Psikologi Universitas 17 Agustus 1945 Surabaya, Indonesia \\ ${ }^{1}$ seprie@gmail.com, ${ }^{2}$ andikmatulessy@untag-sby.ac.id
}

\begin{abstract}
Abstrak
FoMO atau Fear of missing out dicirikan oleh adanya keinginan yang besar untuk tetap terus terhubung dengan informasi tentang apa yang sedang dilakukan oleh orang lain di dunia maya (Przybylski et all, 2013). JoMO atau Joy of Mising Out adalah kebalikan dari FoMO. JoMO mengacu pada bagaimana manusia mengambil momentum secara sadar untuk terlepas dunia internet dan mengalami suatu hidup tanpa tergantung pada internet (Crook, 2015). Sejumlah penelitian memaparkan dunia digital telah memberikan pengaruh signifikan terhadap peningkatan kecemasan dan depresi seseorang. Penelitian ini bertujuan untuk mengkaji gaya hidup JoMO yang mampu memberikan pengaruh positif pada kemampuan seseorang untuk resilien terhadap gaya hidup FoMO. Subjek penelitian adalah remaja siswa Sekolah Menengah Atas. Penelitian ini merupakan penelitian kualitatif yang menggunakan metode studi kasus dengan teknik wawancara dan didukung dengan studi pustaka yang mendalam. Data yang dianalisis merupakan hasil wawancara dengan remaja yang memenuhi kualifikasi yaitu memiliki akun media sosial (whatsapp, line, instagram, twitter, dan faceboook) dan aktif menggunakannya. Hasil penelitian menunjukkan bahwa sejumlah perilaku gaya hidup JoMO ternyata memberikan pengaruh yang signifikan terhadap kemampuan subjek untuk resilien dari kecenderungan FoMO. Hasil penelitian ini juga memberikan informasi tentang bagaimana gaya hidup JoMO dapat memberikan dampak positif terhadap kemampuan remaja untuk resilien dari kecenderungan gaya hidup FoMO.
\end{abstract}

Kata kunci : FoMO, JoMO, joy of mising out, fear of missing out, resiliensi, remaja

\section{Latar Belakang}

Teknologi informasi dan komunikasi saat ini telah menjadi bagian yang lekat dengan kehidupan masyarakat sehari hari. Dari lima kriteria generasi yang ada di masyarakat, generasi masyarakat yang paling akrab dengan kehadiran teknologi informasi dan komunikasi (TIK) adalah kelompok generasi milenial atau sering juga disebut dengan istilah Gen Y dan kelompok generasi Z. Sebagai generasi yang hadir 
PSISULA: Prosiding Berkala Psikologi

Vol. 1, 2019

E-ISSN: 2715-002X

bersamaan dengan momen dimana TIK tumbuh dan berkembang dengan pesat, masyarakt Gen Y dan Gen Z menjadi kelompok yang paling terpapar langsung dari efek kemajuan TIK itu sendiri. Sejumlah penelitian terdahulu juga mengungkapkan bahwa pengguna terbanyak dari pengunaan internet yang merupakan produk dari kemajuan teknologi informasi dan komunikasi adalah generasi $\mathrm{Y}$ dan $\mathrm{Z}$ (Sander, Field, Diego, \& Kaplan (2000); Widiana, Retnowati, \& Hidayat (2004); Suprapto \& Nurcahyo (2005); Ekasari \& Dharmawan, (2012) ; Yen, dkk. (2014); serta Malik \& Rafiq (2015).

Teknologi informasi dan komunikasi memberikan begitu banyak kemudahan. Dengan kemajuan TIK saat ini, dunia sudah ada di dalam genggaman. Di sisi lain, kehadiran TIK perlahan lahan juga menghasilkan efek samping negatif yaitu ketergantungan kepada pengguna TIK itu sendiri. Salah satu fenomena yang kini cenderung menjadi kebutuhan pengguna teknologi informasi dan komunikasi yaitu kebutuhan untuk terus mengikuti apa yang sedang terjadi di luar sana.

Fenomena kehawatiran untuk tidak up to date terhadap apa yang terjadi dikenal dengan istilah Fear of Missing Out yang disingkat dengan istilah FoMO. Menurut Przyblylski, Murayama, DeHaan dan Gladwell (2013) Fear of Missing Out atau FoMO merupakan ketakutan akan kehilangan informasi momen berharga tentang orang atau kelompok lain di mana individu yang bersangkutan tidak dapat hadir didalam momen dan ditandai dengan keinginan untuk tetap terus terhubung dengan apa yang orang lain lakukan melalui internet atau dunia maya. Secara sederhana FoMO dapat didefinisikan sebagai ketakutan akan ketertinggalan informasi yang sedang terjadi. Terdapat banyak penelitian penelitan terdahulu yang telah memaparkan fenomena FoMO sebagai efek samping dari kemajuan teknologi komunikasi dan informasi, antara lain : Claire A. Wolniewicza, Mojisola F. Tiamiyua, Justin W. Weeksb, Jon D. Elhai. (2017); Stella Giagkou1, Zaheer Hussain and Halley M. Pontes. (2018); Dorit Alt, Meyran Boniel-Nissim. (2018); Jon D. Elhai, Jason C. Levine, Robert D. Dvorak, Brian J. Hall. (2016); dan masih banyak lagi.

Berkebalikan dengan FoMO, Joy of Missing Out atau dikenal dengan istiah JoMO adalah cara hidup yang lebih santai dan tidak merasa bermasalah bila 
PSISULA: Prosiding Berkala Psikologi

Vol. 1, 2019

E-ISSN: 2715-002X

terlambat mengetahui sebuah berita. Hayley Phelan (2018) dalam artikelnya di majalah The New York Times menuliskan: "JoMO is about disconnecting, opting out and being OK just where you are." Menurut Hayley, suka atau tidak, pada kenyataannya manusia memang membutuhkan teknologi; hanya saja manusia sejogianya tidak membutuhkan teknologi sebanyak yang dipikirkan oleh manusia dan menjadi JoMO adalah tentang bagaimana menemukan keseimbangan itu. Kristen Fuller (2018), seorang dokter dan penulis di Psychology Today, mengatakan pada dasarnya JoMO adalah tentang menjadi puas dengan kehidupan saat ini. Perilaku gaya hidup JoMO memberikan kesempatan kepada seseorang untuk menjalani hidup dalam ritme yang lebih lambat, lebih terfokus pada relasi dengan sesama manusia, kemampuan untuk mengatakan 'tidak', memberikan ruang khusus terhadap diri sendiri yang terlepas dari ketergantungan teknologi, serta memberi kesempatan kepada diri sendiri untuk merasakan segala emosi yang ada. Christina Crook, salah satu penggiat yang mempromosikan gaya hidup JoMO, pengarang buku The Joy of Missing Out, sekaligus pendiri JOMO ${ }^{\mathrm{TM}}$ mengungkapkan bahwa menjadi JoMO adalah suatu usaha mendapatkan momentum yang dilakukan secara sadar untuk mengambil keputusan terputus dari dunia internet dan menjalani kehidupan secara offline.

Resiliensi adalah kemampuan atau kapasitas insani yang dimiliki seseorang atau kelompok atau masyarakat yang memungkinkan merka untuk menghadapi, mencegah, meminimalkan atau bahkan menghilangkan dampak-dampak yang merugikan dari kondisi-kondisi yang tidak menyenangkan, tidak menguntungkan atau bahkan merubah kondisi yang menyengsarakan menjadi suatu hal yang wajar untuk diatasi. Charney dalam Mahmood dan Ghaffar (2014) mendifinisikan resiliensi sebagai suatu proses adaptasi yang dilakukan dengan baik dalam situasi trauma, tragedi, atau peristiwa yang dapat menyebabkan timbulnya stres lainnya. Disebutkan bahwa resiliensi bukanlah suatu ciri kepribadian melainkan upaya yang melibatkan perilaku, pikiran, atau tindakan yang dapat dipelajari oleh siapa saja. Berkaitan dengan konsep, resiliensi bisa dilihat sebagai suatu hasil ataupun sebagai suatu proses. Individu yang memiliki resiliensi akan mampu untuk secara cepat 
PSISULA: Prosiding Berkala Psikologi

Vol. 1, 2019

E-ISSN: 2715-002X

kembali kepada kondisi sebelum trauma, terlihat kebal dari berbagai peristiwaperistiwa kehidupan yang negatif, serta mampu beradaptasi terhadap stres yang ekstrim dan kesengsaraan. Dari pengertian di atas maka secara umum resilensi selalu mengarah kepada pola adaptasi yang sifatnya positif baik itu selama atau setelah individu, kelompok atau masyrakat menghadapi suatu kesulitan atau resiko (Utami dan Avin, 2017). Memiliki resiliensi berarti seorang inividu memiliki kapasitas untuk mengatasi, dan meningkatkan diri dari keterpurukan, dengan merespon secara sehat dan produktif untuk memperbaiki diri, sehingga mampu menghadapi dan mengatasi tekanan hidup sehari-hari.

Berkaitan dengan urain di atas, maka tujuan dari peneltian ini adalah hendak mengidentifikasi apakah perilaku gaya hidup JoMO yang dilakukan oleh para responden yang sekiranya telah membantu mereka untuk mampu bersikap resilien kecenderungan fear of missing out atau bahkan terlepas dari ketergantungan akan dunia digital.

\section{Metode}

Dalam penelitian ini, peneliti menggunakan metode penelitian kualitatif dan studi literatur. Proses penelitian ini menghasilkan data deskriptif berupa kata-kata tertulis atau lisan dari subjek yang diamati. Jenis penelitian yang digunakan peneliti yaitu deskriptif kualitatif karena penelitian ini menganalisis dan mengidentifikasi perilaku gaya hidup JoMO yang dilakukan oleh para responden dan telah membantu respoden untuk mampu bersikap resilien kecenderungan fear of missing out atau bahkan terlepas dari ketergantungan akan dunia digital.

Teknik pengumpulan data yang digunakan oleh peneliti yaitu wawancara. Wawancara dilakukan langsung kepada remaja sebagai sumber utama. Sebagai data pendukung atau sumber data sekunder diperoleh melalui buku, jurnal, data-data dari internet, penelitian terdahulu, artikel dan dokumen lainnya yang berhubungan dengan penelitian joy of missing out, fear of misisng out dan resiliensi. Sebelum memasuki tahap wawancara, responden terlebih dahulu melewati tes sederhana untuk menentukan apakah responden memenuhi kriteria untuk diwawancarai. 
PSISULA: Prosiding Berkala Psikologi

Vol. 1, 2019

E-ISSN: 2715-002X

Subjek kelompok penelitian adalah remaja yang sedang menempuh pendidikan di sekolah menengah atas. Dengan rentang usia antara 15 - 17 tahun, serta memenuhi kualifikasi berikut : memiliki akun media sosial (whatsapp, line, instagram, twitter, dan faceboook) dan aktif menggunakannya. Penelitian dilaksanakan di kota Sidoarjo.

Analisis dilakukan terhadap data berdasarkan logika induktif. Analisis dilakukan berdasarkan dari sesuatu hal yang khusus atau spesifik, sesuai dengan yang diperoleh di lapangan, menuju ke arah suatu temuan yang bersifat umum, yang akan muncul lewat analisis data berdasarkan teori yang digunakan.

\section{Hasil}

Peneliti mengumpulkan data melalui wawancara dan studi pustaka dan kemudian melakukan analisis deskriptif terhadap perilaku JoMO yang dijalani oleh repsoden penelitian dan pengaruhnya terhadap kemampuan repsonden untuk resilien terhadap perilaku FoMO dan ketergantungan akan dunia digital.

Hasil yang diperoleh dari analisis hasil wawancara yaitu bahwa terdapat sejumlah perilaku yang dilakukan oleh responden penelitian yang tergolong dalam perilaku JoMO, dimana perilaku tersebut membantu para resonden penelitian untuk mampu bersikap resilien terhadap kecenderungan perilaku FoMO.

\section{Diskusi}

Studi ilmiah yang membahas secara spesifik tentang gaya hidup JoMO memang masih sangat sedikit. Agak berbeda dengan studi ilmiah tentang gaya hidup FoMO yang telah diteliti oleh banyak peneliti. Dari hasil penelusuran digital, istilah JoMO pertama kali tercetus pada tahun 2012 dari seorang pengusaha entrepreneur, Anil Dash yang juga seorang aktivis dan penulis. Sejak itu mulai banyak tulisan tentang gaya hidup JoMo namun belum banyak penelitian akademik yang secara khusus membahas tentang JoMO sebagai bagian dari variabel penelitian. 
PSISULA: Prosiding Berkala Psikologi

Vol. 1, 2019

E-ISSN: 2715-002X

Walau belum ada penelitian ilmiah yang secara khusus membahas tentang JoMO dan dampaknya pada kemampuan seseorang untuk resilien terhadap kecenderungan FoMO, namun banyak orang meyakini, gaya hidup JoMO dapat menjadi antidote terhadap gaya hidup FoMO. Alasan mengapa gaya hidup JoMO dianggap mampu membantu seseorang untuk keluar dari kecenderungan FoMO kiranya bersumber penelitian yang dilakukan oleh Harvard Study of Adult Development yang telah berlangsung lebih dari 75 tahun tentang kehidupan orang dewasa. Studi ini dimulai pada tahun 1938 dengan subjek penelitian berjumlah 724 orang yang terbagi atas dua kelompok yaitu Grant Study dan Glueck Study. Penelitian yang dilakukan meliputi:

- Kuesioner, dilakukan setiap dua tahun yang menanyakan tentang kesehatan fisik dan mental, kualitas pernikahan, karir dan kebahagian dimasa pensiun dan lain sebagainya.

- Informasi kesehatan, dilakukan setiap lima tahun dimna informasi mengenai kesehatan dari subjek penelitian dikumpulkan dari responden dan dokter untuk menilai kesehatan fisik para responden.

- Wawancara, dilakukan setiap 5 - 10 tahun untuk mendokumetasikan lebih banyak informasi yang lebih dalam tentang relasi yang dimiliki oleh para responden, tentang karir, dan penyesuaian diri mereka terhadap penuaan.

Penelitian tersebut tidak hanya berhenti pada 724 subjek penelitian awal; namun lebih lagi dilanjutkan kepada generasi keturunan subjek penelitian pertama dengan total lebih dari 2000 orang.

Hasil penelitian yang panjang tersebut menghasilkan satu kesimpulan yang tidak terduga sebelumnya. Robert Waldinger (2015), seorang psikiater Harvard, pendeta zen, dan psikoanalis yang juga merupakan pemimpin generasi ke 4 dari penelitian Harvard Study of Adult Development, dalam suatu talkswow di TEDx Beacon Street mengungkapkan bahwa penelitian panjang tersebut berujung pada satu kesimpulan bahwa : "The clearest message that we get from this 75-year study is this: Good relationships keep us happier and healthier". Hubungan yang baik membuat kita lebih bahagia dan sehat. Hasil studi tersebut dengan jelas 
PSISULA: Prosiding Berkala Psikologi

Vol. 1, 2019

E-ISSN: 2715-002X

menekankan pada pentingnya menjalin relasi yang mendalam dengan orang orang yang berada di sekitar kita.

Relasi positif yang mendalam menjadi inti dari hasil penelitan Harvard Study of Adult Development. Secara esensial, relasi positif yang mendalam dengan orang disekitar kita menjadi inti dari gaya hidup JoMO. Gaya hidup JoMO mengajak seseorang untuk lebih menikmati hidup dengan lebih lambat, berfokus pada kehidupan saat ini, dan membangun relasi yang hangat dengan orang orang disekitar (Kristen Fuller, 2018). Gaya hidup FoMO yang menuntut seseorang untuk terus terkoneksi dengan dunia digital membuat orang sulit untuk menikmati apa yang sedang dijalaninya saat itu juga. Dalam sebuah seminar, Robert Waldinger (2017) kembali mengungkapkan bahwa seringkali orang berusaha untuk terus terkoneksi hanya agar tidak merasa tertinggal dengan apa yang terjadi atau dengan apa yang sedang dilakukan oleh orang lain, dan membuat momen yang harusnya momen "face to face time" dengan orang lain berubah menjadi "face screen time".

Dari hasil wawancara dengan responden penelitian ditemukan sejumlah kesamaan perilaku yang sesuai dengan aspek yang ada di dalam perilaku JoMO yaitu:

- Memiliki pengalaman solitude

Marano (2018) mengartikan solitude sebagai keadaan sendirian tanpa ada rasa kesepian. Keadaan ini dapat membawa pada suatu tahap yang menimbilkn suatu kesadaran diri. Solitude berbeda dengan Loneliness. Solitude merupakan suatu tindakan menyendiri yang diambil secara sadar dan melibatkan keterlibatan yang positif dan konstruktif dengan diri sendiri.

Seluruh responden mengemukakan bahwa mereka seringkali secara sadar memutuskan untuk masuk pada suasana solitude. Secara umum para responden merasakan bahwa dengan masuk pada suasana solitude para responden mampu merasa lebih tenang dan jernih dalam melihat peristiwa yang terjadi. Galanaki (2004) dalam penelitiannya mengungapkan bahwa anak anak yang mampu mengalami solitude dapat menggunakan keadaan tersebut untuk menumbuhkan rasa damai, tenang, berkurangnya ketegangan, 
PSISULA: Prosiding Berkala Psikologi

Vol. 1, 2019

E-ISSN: 2715-002X

memberikan pengaruh positif yang dapat membantu untuk melihat segala sesuatunya dengan lebih jelas. Sabrina Barr (2019), menuliskan bahwa salah satu aspek dari gaya hidup JoMO yaitu kemampuan untuk menikmati waktu sendirian dan tidak merasa pusing emikirkan apa yang sedang dilakukan orang lain di luar sana.

Para responden melewati masa solitude-nya dengan berbagai kegiatan yang berbeda beda, mulai dari membaca buku dalam kamar, mendengarkan lagu, bersepeda mengitari perumahan, memancing, memesan minuman dan makanan kecil untuk dinikmati sendiri, hingga mewarnai buku gambar. Salah satu hasil yang menarik bahwa seluruh kegiatan solitude para responden tidak ada satupun yang membutuhkan koneksi dengan internet.

- Memutuskan koneksi dengan media sosial ketika sedang bersama teman teman dan atau keluarga

Salah satu gadget yang sering dipakai untuk aktif bermedia sosial yaitu dengan mengunakan ponsel. Telah menjadi rahasia umum bahwa ponsel telah ikut memengaruhi interaksi sosial yang ada dalam masing-masing anggota keluarga dan masyarakat. Lestari, Riana, \& Taftarzani (2016), mengungkapkan bahwa dengan kehadiran ponsel, interaksi yang pada awalnya dilakukan secara langsung (tatap muka) kini mulai digantikan menjadi interaksi dengan gadget (ponsel). Perubahan dalam pola interaksi sosial dalam keluarga tersebut menghasilkan pola sikap yang menjadi lebih individualis. Sebab perubahan interaksi langsung menjadi interaksi yang lebih sering dilakukan dengan gadget memiliki perbedaan. Diantara peran emosional dan kontak sosial yang tidak dilakukan secara utuh. Dengan memutuskan untuk melepaskan koneksi dengan media sosial pada saat sedang bersama dengan orang di sekeliling membuat bahwa kontak sosial adalah mejadi lebih hangat, dimana hubungan antara satu orang atau lebih terjadi melalui percakapan dengan saling mengerti tentang maksud dan tujuan masing-masing.

Hal ini sejalan dengan pendapat Annabel Maw (2018) bahwa JoMO dapat dialami ketika kita mulai menyadari hal hal yang sedang kita lakukan, mampu 
PSISULA: Prosiding Berkala Psikologi

Vol. 1, 2019

E-ISSN: 2715-002X

mengambil keputusan untuk terpisah sejenak dengan media sosial dan fokus pada momen yang ada serta mulai membangun relasi yang riil dan hangat dengan orang disekeliling kita.

\section{Kesimpulan}

Kedua hal yang telah dipaparkan diatas adalah gaya hidup yang telah dijalani oleh seluruh responen penelitian dalam kehidupan keseharian. Pada dasarnya seluruh responden penelitian adalah pengguna aktif yang dalam hidup keseharian juga tetap menggunakan produk hasil dari perkembangan TIK; hanya saja, para responden memiliki kemampuan untuk membatasi diri berkaitan dengan penggunaan prodak hasil dari kemajuan TIK.

Dari hasil penelitian ditemukan bahwa perilaku tertentu yang tergolong ke dalam gaya hidup JoMO ternyata tanpa disadari telah membantu para responden untuk mampu resilien terhadap kecenderungan FoMO. Kiranya hal ini dapat memberikan insight bahwa masih ada harapan untuk membantu orang orang agar bisa terlepas dari fenomena FoMO dan ketergantungan yang berlebihan terhadap dunia digital.

Penelitian ini belum memaparkan aspek perilaku JoMO yang mana yang memberikan pengaruh yang paling besar terhadap kemampuna seseorang untuk dapat resilien terhadap FoMO. Penulis berharap akan ada akademisi lain yang berminat untuk mengkaji lebih dalam lagi tentang JoMO dan manfaatnya terhadap upaya detoksifikasi FoMO.

\section{Daftar Pustaka}

Annabel Maw. 2018. Want To Be Happier? Embrace JOMO. Diakses 12 Maret 2019 dari https://www.jotform.com/blog/embrace-jomo/

Asosiasi Penyelenggara Jasa Internet Indonesia. (2018). Laporan Survey Penetrasi \& Profil Perilaku Pengguna Internet Indonesia. Jakarta : APJII

Badan Pusat Statistik (2016). Statistik Indonesia 2018. Jakarta : Badan Pusat Statistik Indonesia. 
PSISULA: Prosiding Berkala Psikologi

Vol. 1, 2019

E-ISSN: 2715-002X

Barr, Sabrina. (30 Januari 2019). Five Signs You've Swapped Fomo For Jomo. Independent. Diakses Diakses 12 Maret 2019 dari https://www.independent.co.uk/life-style/jomo-fomo-fear-joy-of-missingout-millennials-netflix-spotify-friends-socialise-cinema-a8753626.html

Crook, Christina (2015). The Joy Of Missing Out : Finding Balance In A Wired World. Canada : New Society Publishers

Fuller, Kristen. (26 Juli 2018). JOMO: The Joy of Missing Out. Diakses 12 Maret 2019 dari https://www.psychologytoday.com

Galanaki, Evangelia. (2004). Are children able to distinguish among the concepts of aloneness, loneliness, and solitude?. International Journal of Behavioral Development-INT J BEHAV DEV. 28. 435-443. 10.1080/01650250444000153.

Harvard Study Of Adult Development. (2015). Diakses 12 Maret 2019 dari https://www.adultdevelopmentstudy.org/

Lestari, I., Riana, A. W., \& Taftarzani, B. M. 2014.Pengaruh Gadget pada Interaksi Sosial dalam Keluarga. Prosiding Ks: Riset \&PKM, 2 (2): 204-209.

Mahmood, K. \& Ghaffar, A.(2014). The Relationship between Resilience, PsychologicalDistress and Subjective Well- Being among Dengue Fever Survivors. Global Journal ofHuman-Social Science: Arts \& Humanities,14(10). Publisher: Global Journals Inc.(USA)

Marano, Hara Estroff. (13 Desember 2016). What Is Solitude?. Diakses 12 Maret 2019 dari https://www.psychologytoday.com

Phelan, Hayley. (12 Juli 2018). How to Make This the Summer of Missing Out. New York Times. Diakses dari https://www.nytimes.com

Przybylski, Andrew K., Kou Murayama., Valerie Gladwell., \& Cody R DeHan (2013). Motivational, Emotional and Behavioral Correlates of Fear of Missing Out. Computer in Human Behavior, 29,1841-1848.doi: 10.1016/j.chb.2013.02.014

Sherlyanita, A. K., \& Rakhmawati, N. A. (2016). Pengaruh dan Pola Aktivitas Penggunaan Internetserta. Journal of Information Systems Engineering and Business Intelligence, 17-22. DOI: 10.20473/jisebi.2.1.17-22

TEDxBeaconStreet. (November 2015). Robert Waldinger: What makes a good life? Lessons from the longest study on happiness [video file]. Diakses dari https://www.ted.com/talks/robert_waldinger_what_makes_a_good_life_les sons_from_the_longest_study_on_happiness?language=en

Utami, C.T, \& Helmi, A. F.(2017). Self-Efficacy dan Resiliensi: Sebuah Tinjauan Meta-Analisis. Buletin Psikologi 2017, Vol. 25, No. 1, 54 - 65 DOI: 10.22146/buletinpsikologi.18419ISSN

World Government Summit. (6 April 2017). Robert Waldinger: A 75 Year Study on Human Happines [video file]. Diakses dari https://www.youtube.com/watch?v=f6lgvagrJP0 